\title{
JOURNAL.RU
}

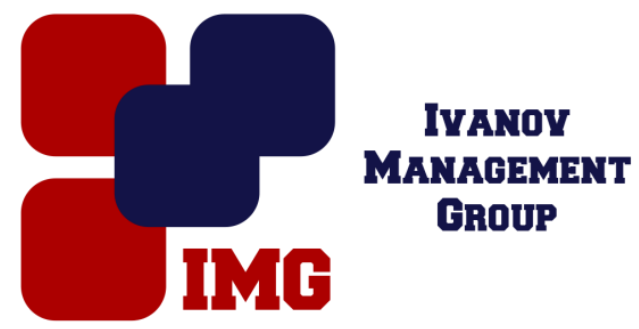

Выгузова А.О.

Байкальский государственный университет Иркутск, Россия

doi: $10.18411 / 1 \mathrm{j}-31-07-2017-48$

idsp 000001:1j-31-07-2017-48

\section{Стратегические направления повышения маркетингового потенциала города Иркутска}

\section{Аннотация}

В данной статье рассмотрены проблемы позиционирования города Иркутска. Рассмотрен вариант позиционирования города, как центр переговоров. Представлен план-воплощение по увеличению мощностей и проведению ребрендинга существующего выставочного комплекса в городе Иркутске.

Ключевые слова: Иркутск, позиционирование, СибЭкспоЦентр, ребрендинг, маркетинговый потенциал.

Основной проблемой реализации маркетингового потенциала города Иркутска- отсутствие позиционирования территории. Иркутск имеет определенные ресурсы, географическое положение, система образования и т.п., имея много ресурсов,никак не выделяется, следовательно, территорией никто не занимается.

Для решения данной проблемы необходимо развивать стратегию позиционирования территории города Иркутска.

Необходимо позиционировать город, как центр переговоров между Европой и Азией. Существует как минимум три причины, которые позволяют рассматривать Иркутск как международную площадку для переговоров. Вопервых, Иркутск расположен на пересечении основных транспортных магистралей-город перекресток. Во-вторых, он представляет дополнительный 
интерес для бизнес-элиты как столица Байкальского туристического региона. Втретьих, здесь уже действует крупный выставочный комплекс СибЭкспоЦентр, который давно стал коммерческим центром Восточной Сибири.На его базе необходимо создать данную площадку(рис.1).

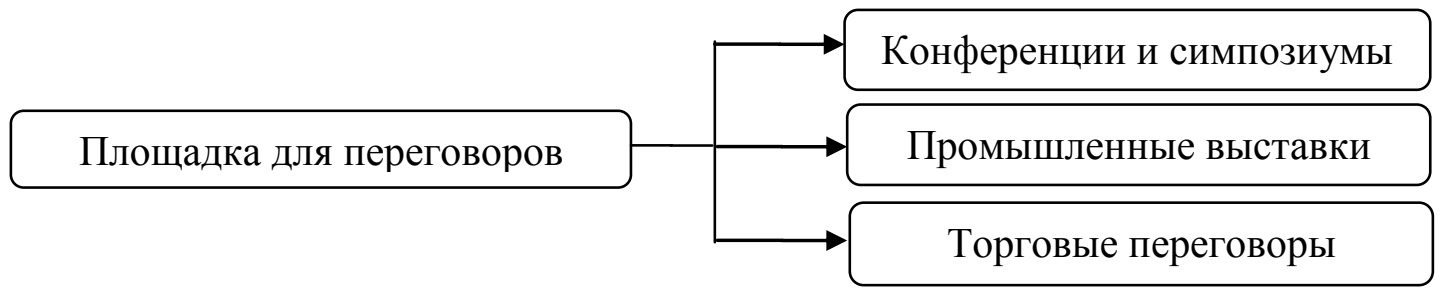

Рис. 1.Варианты использования новой площадки

Байкальский форум, который проходит раз в два года в Иркутске, в последнее время все больше фокусируется на обсуждении общих экономических интересов стран Азиатско-Тихоокеанского региона и Дальнего Востока. Так что этот город может поспорить с Владивостоком за статус коммуникативного центра, представляющего интересы России в АТЭС. Правда, это возможно только при одном условии - если у администрации Иркутска есть соответствующие амбиции, и она готова проводить кропотливую маркетинговую работу [1].

На данный момент СибЭкспоЦентр находится не в том состоянии, чтобы принимать крупных деловых партнеров. Необходимо провести ребрендинг для усиления его уникальности, привлечения новых потребителей и увеличения производственных мощностей.

План-воплощение выставочного комплекса СибЭкспоЦентр:

1) Увеличение производственных мощностей

- Расширение территории комплекса, за счет близлежащих пустых территории. Потенциальная территория комплекса после расширения 190000 кв.м.;

- Постройка гостиничного комплекса на территории СибЭкспоЦентра;

- Реконструкция и обустройство существующих павильонов;

- Благоустройство открытых зон;

- Постройка нового трехэтажного главного здания;

- Строительство парковочной площадки;

- Строительство концертной площадки;

- Закупка современного технического оборудования:

2) Ребрендинг 
Слоган - важная составляющая бренда города.

Наш слоган: Иркутск - город соглашений!

- Создания нового названия и логотипа (рис.2);

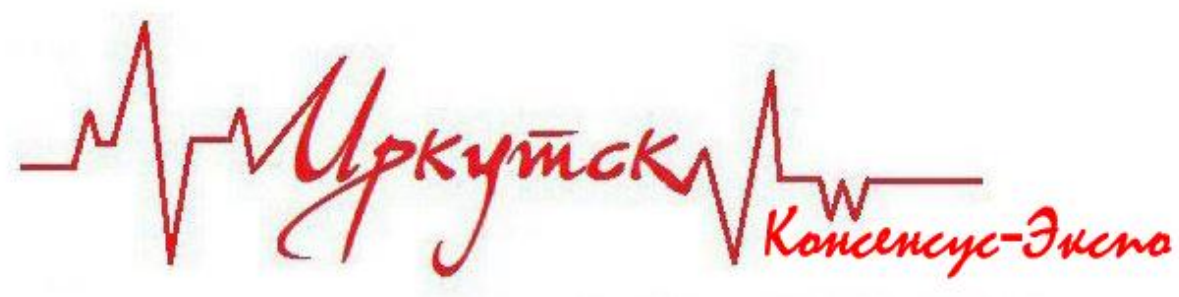

Рис.2. Новый логотипСибЭкспоЦентра, как продукта территории

- Создание единого и уникального дизайна для всего выставочного комплекса СибЭкспоЦентр;

- Создание имиджа города новых технологий;

- Создание сайта;

- Создание информационной компании.

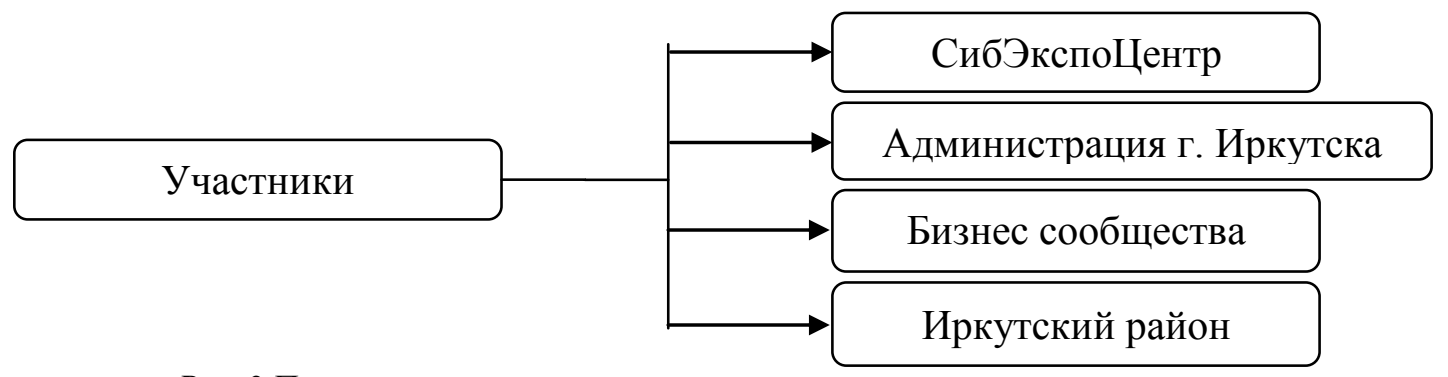

Рис. З.Перечень участников проекта муниципально-частного партнерства

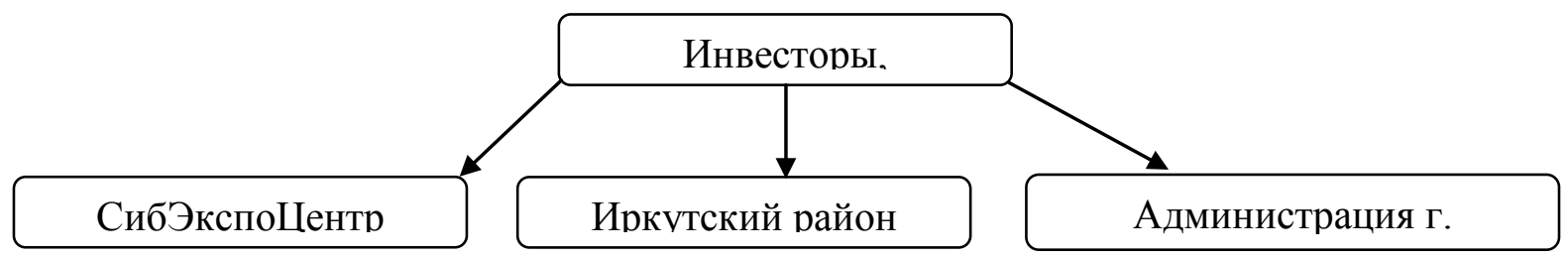

Рис.4. Инвесторы проекта

Финансировать проект необходимо администрации города и СибЭкспоЦентру, но также и Иркутскому району, так как после выставочного комплекса многие участники переговоров, выставок и т.д. будут отправлены с экскурсией в поселок Листвянка.

Для развития данного проекта и донесения информации необходимо провести информационную компанию. Реклама - самое главное, она должна быть грамотно составлена. Большую часть информации общество узнает из Интернета, поэтому необходимо создать новый сайт, рекламироваться в социальных сетях, это существенно снизит затраты на рекламу. Рассылка электронных писем целевым потребителям(рис.5). 


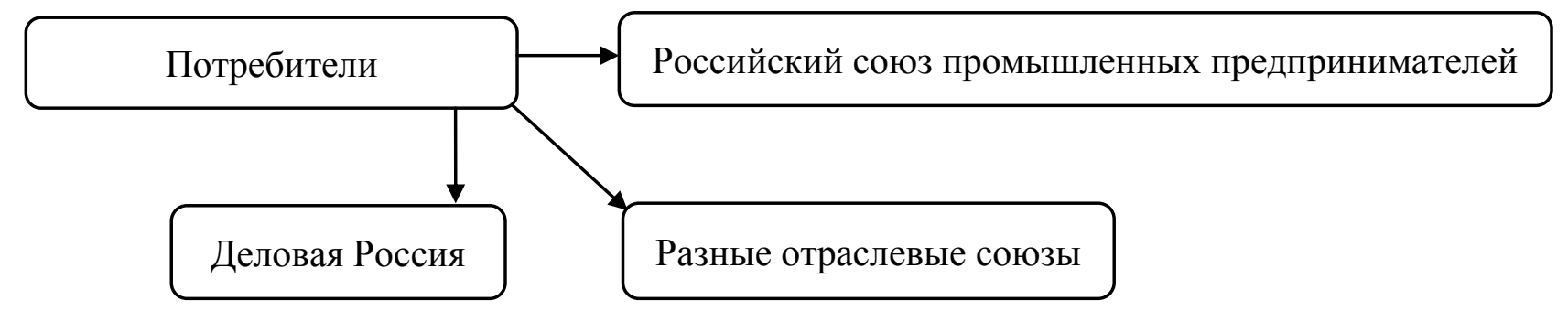

Рис.5. Целевые потребители

Все участники такого проекта могут рассчитывать на определенные выгоды от его реализации. Но, самый значимый результат, это реализация потенциала города Иркутска и повышение его привлекательности.

***

1. Визгалов Д.В. Маркетинг города. - М.: Фонд "Институт экономики города". - 2008 г. - 144 c.

2. Википедия Иркутск [Электронный ресурс]. Режим доступа: https://ru.wikipedia.org/wiki/Иркутск.

3. Официальный портал города Иркутска [Электронный ресурс]. Режим доступа: http://admirk.ru/

4. Официальный портал выставочного комплекса СибЭкспоЦентр [Электронный ресурс]. Режим доступа: http://www.sibexpo.ru. 